\title{
Synthesis, Characterization and Biological Evaluation of a Series of Levofloxacin Carboxamide Analogues
}

\author{
Najma Sultana, Muhammad Saeed Arayne, ${ }_{, . *}$ Syeda Bushra Shakeb Rizvi, ${ }^{\dagger}$ and Muhammad Ahmed Mesaik ${ }^{\ddagger}$
}

\author{
Department of Pharmaceutical Chemistry, Faculty of Pharmacy, Lniversity of Karachi-75270, Pakistan \\ ${ }^{\dagger}$ Department of Chemistrv. Unversity of Karachi-75270. Pakistan. 'E-mail: msaramel Oogmail.com or msarawe agmail.com \\ -PChID, International Centre of Chemical Sciences, University of Karachi, Karachi, Pokistan \\ Received June 17, 2009. Accepted Alugust 21.2009
}

\begin{abstract}
In present work an attempt was made to synthesize various analogues of levolloxacin by introducing new functionality at carboxylic group position via nucleophilic substitution reaction. For this purpose the carboxylic group at C-6 was esterified and later subjected to nucleophilic attack at the carbonyl carbon by various aromatic amines. Structure of the analogues was confirmed by different techniques i.e. $\mathbb{R},{ }^{1} \mathrm{HNMR}$ and mass spectrometry. The antibacterial activity of the derivatives was also assessed and conpared with the parent against a series of Gram-positive and Gramnegative bacteria. A synergistic as well as antagonistic behavior was observed in these derivatives. Additionally unlike levofloxacin, the derivatives were also found to modulate oxidative burst response of phagocytes exhibiting noderate to significant inhibitory activity.
\end{abstract}

Key Words: Levofloxacin. Nucleophilic substitution reaction, Antibacterial activițy Sỵnergistic. Antagonistic

\section{Introduction}

Fluoroquinolones have a useful role in the treatment of many bacterial infections. ${ }^{1.2}$ The 4-quinolone originates from $1.8-$ naphythyridine precursor-nalidixic acid. discovered in the early 1960 s. ${ }^{3.4}$ Later on quinolones containing fluorine atoms ${ }^{36}$ were introduced. A broad-spectrum, third-generation fluoroquinolone antibiotic Levofloxacin, (Figure 1) (-)-(S)-9-fluoro-2,3-dilhydro3-methyl-10-(4-methyl-1-piperazinyl)-7-oxo-7 $H$-pyrido[1.2.3de]-1,4-benzoxazine-6-carboxylic acid produces higher ocular tissue penetration diffuses through the bacterial cell wall and acts by inhibiting DNA gyrase (bacterial topoisomerase II), an enzy me required for DNA replication. RNA transcription. and repair of bacterial DNA. Inlibition of DNA gyrase activity leads to blockage of bacterial cell growth. ${ }^{8-11}$

Much effort has been made in recent years to the synthesis of new quinolones for enhanced antibacterial activity. ${ }^{15}$ Structural modifications at all positions of the quinolone nucleus. except the t-oxo group. have successfully led to the discovery of potent antimicrobial agents. ${ }^{1 ?}$

Most of the quinolone antibacterial research has been focused on the functionality at $\mathrm{C}-7$ position. ${ }^{13}$ The structure activity

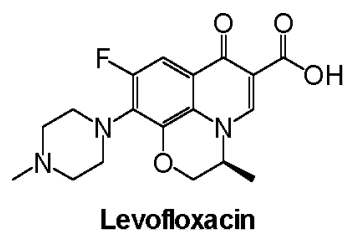

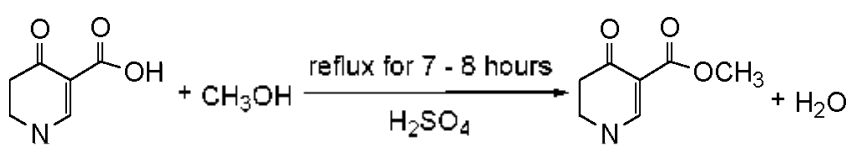

Pyridone ring of levofloxacin Ester Derivative of Levofloxacin

Figure 1 relationship (SAR) reveals that the C-7 substituent is the most adaptable site for chemical change and is an area that determines potency and target preference. ${ }^{14}$ During recent years a number of quinolones with substitution on piperazine ring at $\mathrm{C}-7$ position of the basic structure of quinolones were sy ntthesized. ${ }^{15.17}$ In earlier studies. the substitution of bulky residue on piperazinyl ring of levofloxacin was carried out with 2-aryl-2-oxoethyl or a 2-aryl-2-oxyiminoethyl moiety. ${ }^{18}$ however evidences are found in literature which reports increased antimicrobial profile of the quinolones in the form of carboxylate complexes. ${ }^{19}$ Because of lack of data in the literature concerning analogues of levofloxacin at carboxylic group. we are reporting here a third generation broad spectrum azafluoroquinolone antibacterial agent. by introducing new functionality at carboxylic group position. For this purpose the carbosylic group at $C-6$ was esterified and later subjected to nucleophilic attack at the carbonyl carbon by various aromatic anines.

The present study reports the synthesis (according to figure). spectroscopic analysis (including IR and ${ }^{1} \mathrm{H} N \mathrm{NM}$ ) and evaluation of biological activities of levofloxacin carboxylic derivatives carning amino-containing aromatic ring. The mass spectrometry was also performed to establish the structure.

\section{Expenimental}

Material and equipments. Levofloxacin was gift from Getz Pharmaceutical Laboratories Ltd.. Karachi. Pakistan. All the reagents used were of analytical grade. All the glassware was washed with chromic acid followed by a thorough washing with freshly prepared de-ionized water.

Melting points were obtained manually by capillary method. The IR spectra were obtained on shimadzu prestige-21 $200 \mathrm{VCE}$ coupled to a PIV-PC and loaded with IR solution version 1.2 software (potassium bromide disks). The absorption peaks were recorded in frequency $\left(\mathrm{cm}^{-1}\right)$. NMR spectra were recorded on 
Bruker FT-NMR $500 \mathrm{MHz}$ with the compounds dissolved in deuterated methanol. Chemical shifts are reported in parts per million ( $\delta$ ) relative to tetra methyl silane as an internal standard. Significant ${ }^{l} \mathrm{H}$ NMR data are tabulated in the following order: multiplicity (s. singlet: d. doublet: t. triplet: q. quartet: and m. multiplet): and number of proton (s). The mass spectra were recorded on Finnign-MAT2 12 under electron impact (EI) ionization condition. Thin layer chromatography (TLC) was performed on HSF-25+ TLC plate and compounds visualized under UV lamp.

General procedure forpreparation of derivatives (a-f). Synthesis of various derivative of levofloxacin was attempted with various aromatic amines i.e.. phenylhydrazine. aniline. 0-aminophenol. phenylenediamine. 3-aminophenol and $\alpha$-naphthỵlamine. Levofloxacin (0.1 moles) was added to the round bothomed flask containing $60 \mathrm{~mL}$ of methanol. $1-2$ drops of concentrated sulphuric acid was added to the flask and the reaction was refluxed for about $7 \sim 8$ hours. After the consumption of levofloxacin (monitered by TLC) 0.1 molar solutions of aromatic amines (prepared in methanol) were added individually with continuous stirring and the reaction was again refluxed for about $2 \sim 3$ hours till completion, indicated by TLC. The volume of the reaction mixture was then reduced by rotary-evaporation. The precipitates were filtrated off. washed with methanol-chloroform (2:8) to give compound.

Spectral data. 9-Fluoro-2,3-dihydro-3-methyl- $N$-phenyl-10(4-methyl-1-piperazinyl)-7-oxo-7 $H$-pyrido $[1,2,3-d e]-1,4-b e n-$ zoxazine-6-carbohydrazide (a): Yield $32 \%$ m.p. $292^{\circ} \mathrm{C}$ (dec.). $\mathbb{R}(\mathrm{KBr})$ max: $1669(\mathrm{C}=\mathrm{O})$ and $3225(\mathrm{~N}-\mathrm{H}),{ }^{1} \mathrm{H}$ NMR (MeOD. $300 \mathrm{MHz}) \delta: 8.51(\mathrm{~s}, 1 \mathrm{H} .5$ 'aryl H), $6.3+$ (d. $1 \mathrm{H} .8$ aryl H. $J=$ 13.1) $3.6 \mathrm{l}: 2.59$ (m. $8 \mathrm{H}$. piperznyl H) 2.34 (s. $3 \mathrm{H}$ of piperazinyl $\left.\mathrm{CH}_{3}\right), 4.31-4.22(\mathrm{~m}, 3 \mathrm{H}$, oxazine $\mathrm{H}), 3.65$ (d. $3 \mathrm{H}$ of oxazine ring $\mathrm{CH}_{3 .} J=6.1$ ). $7.5-7.9$ (s. NH of amide). $7.33(\mathrm{~m}, 5 \mathrm{H}$. phenylic H). MS (m/z. \%): (452.21. 15) $\mathrm{M}^{+}$. Anal. Calcd for $\mathrm{C}_{24} \mathrm{H}_{26} \mathrm{FN}_{5} \mathrm{O}_{3}$ : C. $63.85:$ H, 5.80; F. 4.21; N. 15.51; Found C, 63.36: H, 5.27: F, 4.07: N, 15.67

9-Fluom-2,3-dihydro-3-methyl- $N$-phenyl-10-(4-methyl-1piperazinyl)-7-ox0-7 $H$-pyrido $[1,2,3-d e]-1,4-$ benzoxazine-6carboxamide (b): Yield $71 \%$ m.p. $301^{\circ} \mathrm{C}$ (dec.). IR (KBr) v max: $1641(\mathrm{C}=\mathrm{O})$ and $3305(\mathrm{~N}-\mathrm{H}) .{ }^{\mathrm{l}} \mathrm{H} \mathrm{NMR}(\mathrm{MeOD}, 300 \mathrm{MHz}) \delta$ : $8.5+$ (s. 1H, 5 aryl H), $6.2+$ (d. 1H. 8 aryl H. $J=13.5$ ) . 3.62: 2.57 (m, 8H, piperznyl H), 2.37 (s. $3 \mathrm{H}$ of piperazinyl $\mathrm{CH}_{3}$ ). $4.31-4.25$ (m. $3 \mathrm{H}$. oxazine $\mathrm{H}$ ). 3.69 (d. $3 \mathrm{H}$ of oxazine ring $\mathrm{CH}_{3}$. $J=6.7) .7 .5-7.9$ (s. NH of anide). 7.31 (m. $5 \mathrm{H}$, phenylic $\mathrm{H}$ ). MS $(m / z, \%):(437.19,42) \mathrm{M}^{+}$. Anal. Calcd for $\mathrm{C}_{24} \mathrm{H}_{23} \mathrm{FN}_{4} \mathrm{O}_{3}: \mathrm{C}$. 66.04: H. 5.77: F. 4.35: N. 12.84: Found C. 66.19: H. 5.64: F, $4.25 ;$ N. 12.54 .

9-Fluo 10-2,3-dihydro-3-methyl- $N$-(3-hy roxyphenyl)10-(4methyl-1-piperazinyl)-7-0x0-7H-pyrido[1,2,3-de]-1,4-benzoxazine-6-carboxamide (c): Yield $52 \%$ m.p. $298^{\circ} \mathrm{C}$ (dec). IR $(\mathrm{KBr}) v_{\max }: 1649(\mathrm{C}=\mathrm{O})$ and $3064(\mathrm{~N}-\mathrm{H}) .{ }^{1} \mathrm{H}$ NMR (MeOD. $300 \mathrm{MHz}) \delta: 8.57(\mathrm{~s}, 1 \mathrm{H} .5$ aryl H) 6.40 (d. $1 \mathrm{H} .8$ aryl H. $J=$ 13.3). $3.57: 2.58$ (m. $8 \mathrm{H}$. piperznyl H) 2.34 (s. $3 \mathrm{H}$ of piperazinỵl $\left.\mathrm{CH}_{3}\right), 4.30-4.27(\mathrm{~m}, 3 \mathrm{H}$. oxazine $\mathrm{H}$ ), 3.65 (d, $3 \mathrm{H}$ of oxazine ring $\mathrm{CH}_{3,} J=6.5$ ), $7.5-7.9$ (s. NH of amide) 7.33 (m. $5 \mathrm{H}$. phenylic H). $\mathrm{MS}(m / z . \%)$ : $(+53.19 .26) \mathrm{M}$. Anal. Calcd for $\mathrm{C}_{2} \mathrm{H}_{23} \mathrm{FN}_{4} \mathrm{O}_{4}$ : C. 63.71 : H. 5.57; F. 4.20: N, 12.38; Found C. 63.75: H, 5.71; F. 4.29: N. 12.94
9-Fluoro-2,3-dihydro-3-methỵl- $N$-(2-aminophenỵl) 10 -( 4 methyl-1-piperazinyl)-7-oxo-7 $\boldsymbol{H}$-pyido[1,2,3-de]-1,4-benzoxazine-6-carboxamide (d): Yield $75 \%$, m.p. $280{ }^{\circ} \mathrm{C} . \mathrm{IR}$ (KBr) v'mal: $: 1660(\mathrm{C}=\mathrm{O})$ and $3150(\mathrm{~N}-\mathrm{H}),{ }^{1} \mathrm{H}$ NMR (MeOD, $300 \mathrm{MHz}$ ) $\delta: 8.61$ (s. $1 \mathrm{H}, 5$ aryl H). 6.34 (d. IH. 8 anyl H, $J=$ 13.1). $3.61: 2.60(\mathrm{~m}, 8 \mathrm{H}$, piperznyl H). 2.40 (s, $3 \mathrm{H}$ of piperazimyl $\left.\mathrm{CH}_{3}\right), 4.29-4.25(\mathrm{~m}, 3 \mathrm{H}$, oxazine $\mathrm{H}), 3.68(\mathrm{~d}, 3 \mathrm{H}$ of oxazine ring $\left.\mathrm{CH}_{3}, J=6.1\right), 7.5-7.9(\mathrm{~s}, \mathrm{NH}$ of amide). $7.41(\mathrm{~m}$, $5 \mathrm{H}$, phenylic $\mathrm{H})$. MS $(m / z, \%):(452.21,73) \mathrm{M}^{+}$. Anal. Calcd for $\mathrm{C}_{2} \mathrm{H}_{2} \mathrm{FN}_{4} \mathrm{O}_{3}: \mathrm{C}, 63.85: \mathrm{H}, 5.80: \mathrm{F}, 4.2 \mathrm{I}: \mathrm{N}, 15.5 \mathrm{l}:$ Found C. $63.55 ;$ H. 5.69; F. 4.10; N. 15.61

9-Fluoro-2,3-dihydro-3-methyl- $N$-(0'hyroxyphenyl) 10-(4methyl-1-piperazinyl)-7-ox0-7H-pyrido[1,2,3-de]-1,4-benzoxazine-6-cartox amide (e): Yield $72 \%$. m.p. $255^{\circ} \mathrm{C}$. R (KBr) $v_{\max }: 1657(\mathrm{C}=\mathrm{O})$ and $3200(\mathrm{~N}-\mathrm{H}) .{ }^{\mathrm{j}} \mathrm{H}$ NMR $\delta: 8.62$ (s. $\mathrm{lH}$. 5'aryl H), 6.45 (d, $1 \mathrm{H}, 8$ aryl $\mathrm{H}, J=13.1), 3.59: 2.57(\mathrm{~m}, 8 \mathrm{H}$, piperznyl H). $2.35\left(\mathrm{~s} .3 \mathrm{H}\right.$ of piperazinyl $\left.\mathrm{CH}_{3}\right) .4 .3 \mathrm{l}-4.23(\mathrm{~m}, 3 \mathrm{H}$, oxazine $\mathrm{H}$ ). 3.71 (d. $3 \mathrm{H}$ of oxazine ring $\mathrm{CH}_{3 .} J=6.1$ ). $7.5-7.9(\mathrm{~s}$, $\mathrm{NH}$ of amide). 7.38 (m. $5 \mathrm{H}$, phenylic $\mathrm{H}$ ). $\mathrm{MS}(\mathrm{m} / \mathrm{z} \%$ ): (453.19. 26) $\mathrm{M}^{+}$. Anal. Calcd for $\mathrm{C}_{24} \mathrm{H}_{25} \mathrm{FN}_{4} \mathrm{O}_{4}$ : C. 63.71: $\mathrm{H}, 5.57: \mathrm{F}$, 4.20: N, 12.38; Found C. 63.77: H, 5.22: F, 4.25: N, 12.54 .

9-Fluoro-2,3-dihydio-3-methyl- $N$-(naphthalen-1-yl)10-(4methyl-1-pijeraziny])-7-ox0-7 H-pyrido[1,2,3-de]-1,4-benzoxazine-6-caboxamide (f): Yield $65 \%$, m.p. $26 \mathrm{I}^{\circ} \mathrm{C}$. IR (KBr) $v_{\text {max: }}: 1662\left(\mathrm{C}=\mathrm{O}\right.$ ) and $3157(\mathrm{~N}-\mathrm{H})$. ${ }^{\mathrm{l}} \mathrm{H} \mathrm{NMR} \delta: 8.53(\mathrm{~s} . \mathrm{H}$, $5^{\circ}$ añl H), 6.35 (d. lH. 8 añl H. $\left.J=13.5\right), 3.63: 2.61$ (m. $8 \mathrm{H}$. piperznyl H). $2.39\left(\mathrm{~s} .3 \mathrm{H}\right.$ of piperazinyl $\left.\mathrm{CH}_{3}\right) .4 .3 \mathrm{l}-4.27(\mathrm{~m}, 3 \mathrm{H}$, oxazine $\mathrm{H}$ ). 3.71 (d. $3 \mathrm{H}$ of oxazine ring $\left.\mathrm{CH}_{3} . J=6.1\right) .7 .5-7.9(\mathrm{~s}$, $\mathrm{NH}$ of amide). 7.42 (m. $7 H$, phenylic H). MS (m/z.\%): (453.19. 26) $\mathrm{M}$. Anal. Calcd for $\mathrm{C}_{2} \mathrm{H}_{2}-\mathrm{FN}_{4} \mathrm{O}_{3}$ : C. 69.12; H. 5.59; $\mathrm{F}$, 3.90: N. 11.52: Found C. 69.84: H. 5.82: F. 3.72: N. 11.59.

Antimicrobial assay. The antinicrobial susceptibility of all the derivatives was tested by the disc diffusion teclunique developed by Bauer et al ${ }^{\text {yj }}$ For this purpose $50 \mathrm{ppm}$ stock solution of levofloxacin and its derivatives were prepared. The stock solution was diluted to 3 different concentrations i.e. 5, 10 and $20 \mathrm{ppm}$. Commercially available filter paper discs were soaked in the prepared drug and derivatives solution dried and applied on the surface of solid culture media (Nutrient Agar). which had been streaked with standardized bacterial inoculums and incubated at $37^{\circ} \mathrm{C}$ for $24 \mathrm{~h}$. This method is based on the determination of an inhibited zone proportional to the bacterial susceptibility to the antimicrobial present in the disk.

The results were compared with the parent against 11 different strains of Gram positwe (Staphylococcus aureus. Bacilhis subtilis, Streptococcus pneumonice. Cornnebacteritm hoffmanmii) and Gram negative organisns (Klebsiella pnemmoniae, Proteus mirabilis, Shigella flexneri. Escherichia coli. Pseudomonas areuginosa. Citrobacter species, and Salmonella rupi).

Phagocyte chemiluminescence. Luminol-enhanced chemiluminescence assay was performed using Helfand $t$ t al protocol. ${ }^{2 l}$ Briefly whole blood diluted in modified Hank's solution was incubated with different concentrations of the derivatives $(100.50,25.6 .25$ and $3.1 \mu \mathrm{g} / \mathrm{mL})$ for $30 \mathrm{~min}$. Zy mosan (Sigma Chemical Co. USA) $100 \mu \mathrm{L}(20 \mathrm{mg} / \mathrm{mL})$, followed by $100 \mathrm{uL}\left(7 \times 10^{5} \mathrm{M}\right)$ luminal (Signta Chenucal Co.. USA) was added to make a final volume of $0.25 \mathrm{~mL}$. MHS alone was run as a control. Peak chemiluminescence was recorded with a 
luminometer (Labsystem Luminoskan RS, Finland). The luminometer was set with repeated scan mode. 50 scans with $30 \mathrm{~s}$ intervals and one second point measuring time.

\section{Result and Discussion}

FTIR analy sis showed broad $\mathrm{OH}$ stretching vibration of the carboxylic group of levofloxacin extending from $3600-3100$ $\mathrm{cm}^{-1}$ and strong absorption peak at $1675-1707 \mathrm{~cm}^{-1}$ due to keto carboxylic group. Our studies revealed that in the spectra of all the derivatives of levofloxacin the absorption intensity of the carboxylic carbonyl group was decreased and shifted to the right near $1650 \mathrm{~cm}^{-1}$ which is indicative of the formation of amide. In the spectra of $\mathbf{a} \mathbf{b}$. $\mathbf{d}$ and $\mathbf{f}$ no peak was observed for carboxylic $\mathrm{OH}$ absorption and a distinct. strong and un-obscured $\mathrm{NH}$ stretch was observed at $3200 \mathrm{~cm}^{-1}$ indicating that carboxylic site reacted with the selected amines forming amides. On the other hand. the spectra of $\mathbf{c}$ and e showed sharp $\mathrm{NH}$ absorption near $3000 \mathrm{~cm}^{-1}$ and also $\mathrm{OH}$ stretch at $3600 \mathrm{~cm}^{-1}$ as a sharp band due to the presence of free hydrosyl group in the structure of the selected amines.

The spectra of derivatives were similar to the levofloxacin spectrum except the resonance of acidic proton at 11 ppm which was absent in all derivatives spectra. showing the utilization of this moiety in amide formation. Along with the disappearance of carboxylic proton, all derivatives also showed a singlet in the region 7.5 - 7.9 ppm which corresponds to the absorption of sec-amide. The signals for the aliphatic and piperazinyl protons were practically remain same as they were distant from the group modification site of the drug. Further signals corresponding to their respective chenical structure are mentioned in the spectral data.

The electron inpact mass spectra (EIMS) of levofloxacin showed $\mathrm{M}^{-}$peak at $m / z 36 \mathrm{l}$ which is also the base peak. The fragmentation pattern follows: $m / z 316$ (loss of carboxylic group). $m / 2262$ (loss of piperazinyl ring). $m / z 218$ (loss of both piperazinyl and carboxylic group) and $m / z 203$ (additional loss of methyl group). However all the compounds showed a very low percentage of $\mathrm{M}^{-}$peaks owing to their unstable nature.

The fluoroquinolones comprise a major class of antibacterial chemotherapeutic agents. which have a broad spectnum of activity against Gram positive and Gram negative bacteria. The antibacterial activity generated by fluoroquinolones is caused by the inhibition of two bacterial enzymes: DNA gyrase (a topoiso-

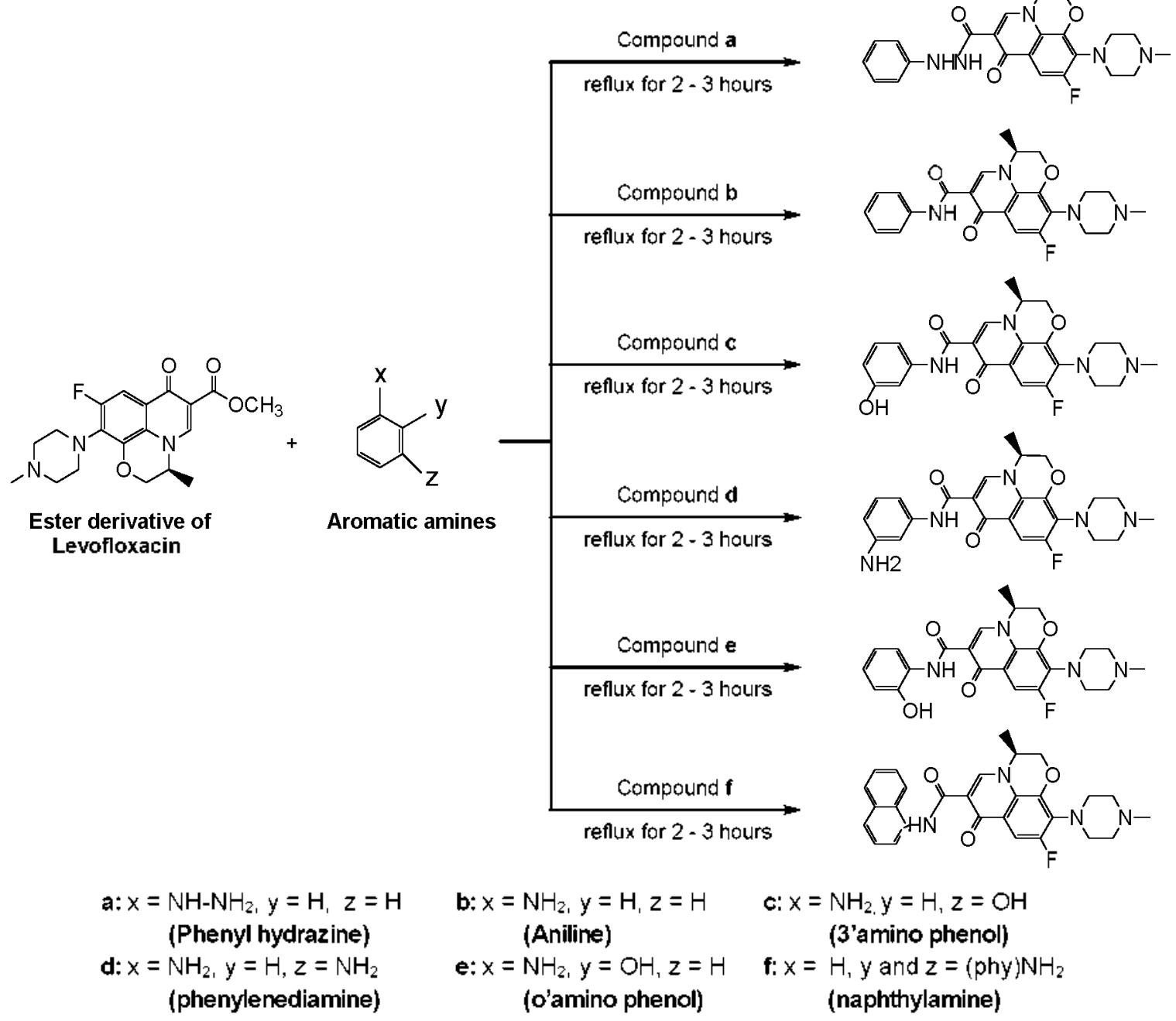

Figure 2. Synthetic Pathway of levofloxacin carboxamide analogues. 
Table 1. Zone (mm) of inhibition of Levofloxacin and its derivatives at different concentrations $(5,10,20 \mathrm{ppm})$.

\begin{tabular}{|c|c|c|c|c|c|c|c|c|c|c|c|c|c|c|c|c|c|c|c|c|c|c|}
\hline \multirow{3}{*}{ S. No. } & \multirow{3}{*}{ Microorganisms } & \multicolumn{3}{|c|}{ Levofloxacin } & \multicolumn{3}{|c|}{$\mathbf{a}$} & \multicolumn{3}{|c|}{ b } & & \multicolumn{3}{|c|}{ d } & \multicolumn{3}{|c|}{ e } & \multicolumn{3}{|c|}{ f } \\
\hline & & 5 & 10 & 20 & 5 & & 20 & 5 & 10 & 20 & 5 & 10 & 20 & 5 & & & 5 & 10 & 20 & 5 & 10 & 20 \\
\hline & & \multicolumn{3}{|c|}{ (ppm) } & \multicolumn{3}{|c|}{ (ppm) } & \multicolumn{3}{|c|}{ (ppm) } & \multicolumn{3}{|c|}{ (ppm) } & \multicolumn{3}{|c|}{ (ppm) } & \multicolumn{3}{|c|}{ (ppm) } & \multicolumn{3}{|c|}{ (ppm) } \\
\hline 1 & Staphylococcus atrens & 8 & 12 & 18 & 11 & 6 & 25 & 12 & 16 & 27 & 9 & 11 & 18 & 13 & 15 & 28 & 9 & 13 & 19 & 11 & 14 & 25 \\
\hline 2 & Citro & 15 & 18 & 21 & 16 & 20 & 22 & 14 & 19 & 20 & 14 & 17 & 20 & 16 & 20 & 22 & 16 & 20 & 21 & 6 & 0 & 22 \\
\hline 3 & S. pnetmonic & 13 & 16 & 22 & 15 & 21 & 32 & 12 & 19 & 23 & 12 & 15 & 22 & 14 & 17 & 24 & 15 & 19 & 22 & 14 & 18 & 24 \\
\hline 4 & Shigella fle- & 10 & 12 & 15 & 11 & 3 & 17 & 12 & 17 & 26 & 14 & 15 & 22 & 11 & 13 & 17 & 15 & 18 & 24 & 12 & 14 & 16 \\
\hline 5 & Esch & 14 & 16 & 22 & 12 & 15 & 20 & 13 & 15 & 19 & 14 & 15 & 21 & 12 & 15 & 20 & 15 & 18 & 22 & 12 & 15 & 20 \\
\hline 6 & Salmonellat & $1 \hat{3}$ & 15 & 17 & 11 & 14 & 15 & 12 & 14 & 16 & 12 & 15 & 18 & 11 & 14 & 15 & 14 & 15 & 19 & 12 & 14 & 16 \\
\hline 7 & Pseudomo & 13 & 14 & 14 & 14 & 16 & 18 & 13 & 14 & 16 & 13 & 15 & 16 & 10 & 11 & 12 & 12 & 15 & 16 & 14 & 15 & 16 \\
\hline 8 & Bacillus subtilis & 10 & 12 & 14 & 13 & 17 & 29 & 9 & 13 & 15 & 10 & 13 & 15 & 9 & 11 & 12 & 11 & 13 & 15 & 9 & 11 & 22 \\
\hline 9 & Klebsiella pnezmoniae & 12 & 16 & 21 & 13 & 18 & 24 & 11 & 17 & 22 & 11 & 12 & 18 & 13 & 18 & 24 & 10 & 18 & 22 & 13 & 18 & 28 \\
\hline 10 & Proteus mirabilis & 11 & 12 & 14 & 12 & 15 & 18 & 12 & 13 & 14 & 13 & 17 & 24 & 12 & 15 & 18 & 14 & 18 & 26 & 12 & 14 & 16 \\
\hline 11 & Conylebacterim hofmanmin & 10 & 10 & 12 & 13 & 16 & 27 & 10 & 12 & 13 & 11 & 11 & 12 & 11 & 15 & 15 & 12 & 14 & 13 & 11 & 13 & 15 \\
\hline
\end{tabular}

$\mathbf{a}=$ Phenyl hydrazine, $\mathbf{b}=$ Aniline. $\mathbf{c}=3$ 'amino phenol. $\mathbf{d}=$ Phenyline diamine, $\mathbf{e}=\mathrm{O}^{\prime}$ amino phenol. $\mathbf{f}=$ Alpha naphthylamine.

Table 2. Oxidative burst activity of $(\mathrm{a}-\mathrm{f})$ in whole blood phagocytes.

\begin{tabular}{cc}
\hline Compound & IC 50 on whole blood $(\mathrm{ug} / \mathrm{mL})$ \\
\hline $\mathbf{a}$ & $<5$ \\
$\mathbf{b}$ & $12.3 \pm 1.2$ \\
$\mathbf{c}$ & $20-25$ \\
d & $20-25$ \\
e & $<5$ \\
f & $13.1 \pm 0.1$ \\
\hline
\end{tabular}

merase enzyme in bacteria) and topoisomerase IV enzyme. ${ }^{\text {.3.?3 }}$ The general function of topoisomerases is to facilitate the uncoiling of DNA during DNA replication. as well as to facilitate the recoiling and packaging of DNA once DNA replication has occurred. ${ }^{3-4}$ Targeting DNA gy rase and topoisomerases may be a way to follow in searching for new chemotherapeutic agents against different microorganisms.

When the aryl group is phenyl $\mathbf{b}$ it was fairly active against Staphylococcus atrets and Shigella flemeri. Introduction of $\mathrm{OH}$ group to aryl amine $\mathrm{c}$ and e showed respectable activity against Proteus mirabilis and Shigella flemeri respectively. Among these compounds, compound d bearing amino group on the phenyl substituent, exhibited the lowest potency against Gram-negative Pseudomonas aretighosa and greater potency against Gram-positive Staphylococcus aureus. When an aromitic ring was introduced to the phenyl substituent $\mathbf{f}$ significant enhancements of potency against Bacillus subtilis, Klebsiella pnetumoniae and Escherichia coli were achieved. It is also worthwhile to point out that formation of hydrazide a at 6 postion exhibited the highest activity against all the Grom-positive strains tested. more potent than reference agent. It is proposed that in the terms of structure-activity relationship. the antibacterial activity profile against Gram-negative bacteria was modulated and enhanced by the phenyl attachment via amide linkage at the 6-position of the levofloxacin molecule.

The overall activity profile of compounds (a-f) against microorganisms revealed that there is remarkable difference in zone of inhibition values as compare to parent. In the terms of structure- activity relationship the antibacterial activity profile against all bacterium was altered by addition of anino group in levofloxacin molecule. The alteration of substitution in amines made marked differences in activity. It seems that expansion of activity is due to better interaction of molecule with target enzymes or for penetration into these bacteria.

Fluoroquinolones have been studied for their innumunodulatory activity. These immunomodulatory effects can be attributed in particular to those flouroquinolones both in vitro and in vivo with a cyclopropyl-moiety at the position $\mathrm{Nl}$ of the quinolone core stricture. The immunomodulatory effects of the flouroquinolones are due to their effects on intracellular cyclic AMP and phosphodiesterases. on transcription factors such as NF-kappa B, activitor protein 1 and a triggering effect on the eucaryotic equivalent of bacterial SOS response. All these studies indicate that fluoroquinolones exert immunomodulatory activities in particular in latent or cluronic infections. ${ }^{26}$

In order to test the immunomodulatory effect of the dnug and its derivatives, we investigated their effect on the oxidative burst activity of whole blood phagocytes. The oxidative burst is an important step in bacterial killing and involves a series of metabolic events that take place when phagocytes are stimulated. resulting in the production of superoxide $\left(\mathrm{O}^{-2}\right), \mathrm{H}_{2} \mathrm{O}_{3}$, and other more potent oxidizing radicals ${ }^{? ?}$, which was then quantified by a luminol-enhanced chemiluminescence assay. Results indicate that the zy mosan- induced oxidative burst in whole blood phagocytes was inhibited (up to $50 \%$ i.e. IC $\mathrm{IC}_{50}$ ) by compounds a and $\mathrm{e}(<5 \mathrm{ug} / \mathrm{nL})$ exhibiting very prominent inlubitory activity. While a moderate inhibitory activity was showed by $\mathbf{b}$ and f. Structure activity relationship of certain inflammatory and inumunomodulatory agents reveals that unlike levofloxacin, the presence of amino benzene nucleus or its amide analogues with varying substitutions are attributed to their immunomodulatory activity and have any effect on the oxidative burst response.

\section{Conclusion}

Development of bacterial resistance has led to the synthesis 
of newer and more potent quinolones. As detailed above. ten carboxylic acid derivatives have been designed. synthesized. characterized and evaluated for their biological activities in vitro in order to discover potent agents against Gram-positive bacteria and Gram negative bacteria.

It was observed that when an aromatic amino group was introduced to carboxy lic side. significant enhancements of potency against organisms were achieved from the levofloxacin nucleus. Moreover some of the derivatives were also found to modulate oxidative burst response of phagocytes. This suggests that they have potential to be anti-inflammatory. as they suppress the production of reactive oxygen species

\section{References}

1. Mascellino, M. T.; Farinelli, S.: Iegri, F.: Iona, E.: De Sinone. C. Drugs Expent. Clin. Res. 1998, 2f, 139-151

2. Hooper, D. C. Biochim. Biophws. Acto 1998, I 400, 45-61.

3. Lesher, G. Y.; Froelich, E. J.: Gruett, M. D.; Bailey, T. H.: Brundage, R. P. Joumal of Meticinal and Phamaceutical Chemistry 1962. $5,1063-1065$.

4. Koga, H.: Itoh, A.; Murayama, S.: Suzue, S.; Irikura, T. Joumat of hedicinal Chenistry 1980, 23(12), 1358-1363

5. Sanders, C. C. Rev. Infect Dis. 1988, 106 3 ), $516-527$.

6. Stephen, V. Adwances in Therapv 2008, 25, 979-994

7. Shen, L. L.: Mitscher, L. A.; Shanna, P. N.: Domnell, T. T.: Chu, D. W. T.; Cooper, C. S.; Rosen, T. Biochemistry 1989, 28, 3886-3894.

8. Crumplin, G. C. Smith, J. T. Antimicrob. Agents Chemother. $1975,8(3), 251-261$

9. Sorgel. F.: Kinzig. M. Am. J Med. 1993, 94, 44S-55S.

10. Sato, K.; Hoshino, K.; Tanaka, M.: Hayakawa, L.; Osada, V. Antinticrob. Agents Chentother. 1992, $36,1491-1498$

11. Kuo, C. F.: Yeh, L. C.: Tia, Y. S.; Tai, C. W.: Cheng, C. T. J.Med.
Chem 2000, 43, 3809-3812.

12. Hooper, D. C.: Wolfson, J. S. In Quinolone Antimicrobial Agents, 2nd ed.; American Society for Microbiology: Washington, D. C. $1993 ; \mathrm{p}+10-413$

13. Seryedehsamira, J; Mohammad, H. M.; Loghman, F; Saeed, E; Saed, R.: Mitra, H.; Farahnaz, P.: Manzarbanoo, E.: Abbas, S.; Alireza, F. Emopean Jomal of Aedicinal Chemistry 2009, 44 . 1205-1209.

14. Domagala, T. M.; Heifetz, C. L.; Hutt, M. P.; Mich, T. F.; Nichols, J. B.; Solomon, M.; Worth. D. F. J. A ked. Chem 1988, $31(5), 991-$ 1001 .

15. Chen, Y. L.; Fang, K. C.; Sheu, J. Y.; Hsu, S. L.; Tzeng, C. C. J. led. Chent 2001, H. $2374-2377$.

16. Foroumadi, A.: Mansouri, S.: Kiani, Z.; Rahmani, A. En: J. Wed. Chem. 2003. $38.851-854$

17. Xiang, M.: Weicheng, Z, Reto, B. Bioonganic \& Medicinal Chemistry Letters 2009,19(3), 986-989.

18. Foroumadi, A.; Emami, S.; Mansouri, S.: Tavidnia, A.; Adeli, N. S.: Shirazi, F. H.: Shatiee, A. European Jomnal of Medicinal Chemistr 2007, $42(7), 985-992$

19. Anacona, J. R.: Toledo, C. Transition Hetal Chemistrv 2001, 26(1), 228-231.

20. Baller, A. W.: Kirby, W. M. M.; Sherris, J. C.: Truck, M. Am. J. Clin. Pathol 1966, 15, 493-496.

21. Helfand, S. L.; Werkmeister, T.; Roder, T. C. J. E.xp. Med. 1982 , $156(2), 492-505$

22. Souza, M. V. N. D. Mini-Rev, Med. Chen $2005,5,1009$

23. Anderson, V. E.: Osheroft, N. Cument Phamacentical Design 2001, 7, 339-355.

24. Champoux, J. T. Ant. Rev. Biochem. 2001, 70, 369-413.

25. Dalhoff, A. Infection 2005, 33, 55-70.

26. Dalhoff, A.; Shalit. I. The Lancet Infections Diseases 2003, $3(6)$. $359-371$

27. Osar, Z.; Samanci, T.; Demirel, G. Y.; Danci, T.; Ilkova, H. Experintental Diab. Res. 2004, $5,155-162$. 